\title{
Usaha Pembuatan Lip blam dari Rumput Laut
}

\author{
Safri Usman
}

Fakultas perikanan Dan Kelautan Universitas Negeri Padang 


\section{PENDAHULUAN}

Perairan Indonesia kaya akan sumber daya hayati laut, salah satunya adalah rumput laut. Rumput laut mengandung berbagai komponen yang dapat dimanfaatkan bagi kehidupan manusia. Rumput laut mempunyai berbagai jenis senyawa polisakarida diantaranya alginat, agaragar, dan karaginan. Selain beberapa kandungan polisakarida dan senyawa bioaktif, rumput laut juga mengandung senyawa lain yaitu pigmen. Rumput laut mempunyai tiga jenis pigmen utama, yaitu klorofil, karotenoid, dan fikosianin. Setiap jenis pigmen tersebut mempunyai berbagai manfaat khususnya bagi kesehatan (Lila, 2004).

Bibir merupakan salah satu bagian wajah yang penampilannya mempengaruhi persepsi estetis wajah. Kulit bibir tidak memiliki folikel rambut dan tidak ada kelenjar keringat yang berfungsi untuk melindungi bibir dari lingkungan luar. Bibir sangat rentan terhadap pengaruh lingkungan serta berbagai produk perawatan kesehatan, kosmetik dan produk perawatan kulit lainnya yang dapat menyebabkan kerusakan kulit yaitu bibir menjadi kering, pecah-pecah, dan warna yang kusam. Untuk menghindari hal tersebut, dibutuhkan antioksidan eksogen yang dapat menunda atau menghambat reaksi oksidasi oleh radikal bebas atau menetralkan dan menghancurkan radikal bebas yang dapat menyebabkan kerusakan sel.

Lip balm merupakan sediaan kosmetik yang dibuat dengan basis yang sama dengan basis lipstik namun tanpa warna, sehingga terlihat transparan. Lip balm merupakan pelembab yang berfungsi untuk melembabkan bibir agar tidak mudah kerring dan pecah-pecah (Nazliniwaty. Dkk. 2019) Biasanya lip balm digunakan untuk bibir yang membutuhkan proteksi, umpamanya pada keadaan kelembaban udara yang rendah atau karena suhu yang terlalu dingin, untuk mencegah penguapan air dan sel- sel epitel mukosa bibir (Kadu et al, 2014).

\subsection{Rumusan Masalah}

1. Apakan pembuatan produk lip blam akan menjadi usaha?

2. Bagaimana rencan atau proses pembuatan produk? 


\subsection{Tujuan}

1. Membuat suatu unit usaha yang menghasilkan keuntungan

2. Mengembangkan produk lokal dengan memanfaatkan rumput laut yang melimpah

3. Meningkatkan kreatifitas dalam suatu kegiatan kewirausahaan dan meningkatkan kepekaan terhadap peluang yang 


\section{GAMBARAN UMUM RENCANA USAHA}

\subsection{Prospek Pengembangan Usaha Lip blam}

Proses pengembangan usaha lip blam yaitu dengan produk kecantikan dan di kemas dengan kemasan cantik, yang bisa d jadikan usaha dan peluang kerja untuk mahasiswa lulusan Teknologi Hasil Perikanan. Harga untuk mendapatkan rumput laut cukup terjangkau untuk di olah menjadi produk kecantikan seperti lip blam.

2.2 Analisis Ekonomi Usaha

Analisis ekonomi usaha lip blam meliputi analisis SWOT sebagai berikut:

$>$ Strengh (Kekuatan)

- Harga produk lib blam yang terjangkau

- Terbuat dari bahan alami

- Memiliki lokasi yang strategis

Weakness (Kelemahan)

- Bahan baku yang sulit di dapatkan di sekitar lokasi produksi

$>$ Opportunity (Peluang)

- Berkembangnya pengetahuan tentang pentingnya menjaga kesehatan organ tubuh terutama bibir di kalangan remaja, akan membuat produk ini menjadi produk yang akan di minati

Threats (Kelemahan)

- Naiknya harga bahan baku

- Munculnya produk baru

\subsection{Tempat}

Produk pembuatan lib blam berada di Desa Milangodaa Kec Tomini Kab Bolaang Mongodow Selatan, lokasi sangat strategis untuk di jadikan tempat usaha produk lip blam. 


\section{BAB III \\ METODE PELAKSANAAN}

\subsection{Usaha Pembuatan lip blam}

Pelaksanaan usaha pembuatan lip blam yaitu dengan memanfaatkan hasil laut, proses pembuatan lip blam di mulai dengan mempersiapakan alat dan bahan yang akan di gunakan pada pembuatan produk.

\subsubsection{Proses pembuatan Lip blam}

1. Proses pembuatan bubur lib blam

$>$ Bahan rumput laut kering

$>$ Di cuci dengan menggunakan air yang di demineralisasi sebanyak 3 kali

$>$ Di rendam menggunakan air yang di demineralisasi (1:20) selama 12 jam

$>$ Di haluskan enggunakan blender dengan di tambah air yang di demineralisasi (1:1) sampai homogen

2. Pembuatan lip blam

$>$ Bahan fase minyak dan air di homogenisasdi pada suhu $\pm 70^{\circ} \mathrm{C}$

$>$ Kemudian di campurkan sediaan fase minyak dan air

$>$ Dibuat perlakuan pembuatan lib blam dan di campurkan bubur rumput pada suhu $\pm 40^{\circ} \mathrm{C}$

$>$ Ditambahkan metil paraben sedikit demi sedikit hingga homogen \pm 10 menit

$>$ Ditambahkan pewangi hingga homogen \pm 3 menit

$>$ Di cetak dan di kemas ke dalam wadah

$>$ Lip blam rumput laut jadi

\subsection{Strategi Usaha}

\subsubsection{Target Usaha}

Target pasar yaitu masyarakat yang ada di sulawesi utara dan gorontalo, terutama untuk pada wanita mauapun pria.

\subsubsection{Strategi Penjual}

Salah satu strategi penjulan adalah offline dan online. Hal ini perlu di lakukan untuk pengembangan produk ini. Kurangnya pemanfaatan hasil laut, makan saya membuat produk lip blam dengan mengguanakan hasil laut yang kaya akan antioksida dan fungsi untuk tubuh. 


\section{BAB IV \\ BIAYA}

4.1 Anggaran Biaya

Ringkasan anggaran biaya di susun sebagai berikut:

\begin{tabular}{|c|c|c|}
\hline No & Jenis Pengeluaran & Biaya \\
\hline 1 & Alat penunjang & 4.000 .000 \\
\hline 2 & Bahan habis pakai & 6.000 .000 \\
\hline 3 & Perjalanan & 1.000 .000 \\
\hline 4 & Lain-lain & 800.000 \\
\hline \multicolumn{2}{|r|}{ Jumlah } & 11.800 .000 \\
\hline
\end{tabular}




\section{REFERENCES}

Abdurrahman, Purbasari S.K, Arsari N.A. 2019. Pembuatan Pelembab Bibir Rumput Laut (Turbinaria sp. Dan E.Cottoni) Untuk Aplikasi Pada Kosmetik Personal Care Lipblam. Fakultas Teknologi Peranian. Bogor

Kadu M, Vishwasrao S, Singh s. 2015. Wiview on Natural Lip Blam. International Journal Of Cosmetic Science 5(1) : 1-7.

Lila M.A 2004. Plant Pigments and Human Health. In: Davis, Plant pigments and Their Manipulation. CRC Press. London. P. 248-274

Nazliniwaty, Laila L, Wahyuni M. 2019. Pemanfaatn Ekstrak Kulit Buah Delima (Punica granatum L) dalam Formulasi Sediaan Lip Blam. Jurnal Jamu Indonesia. Vol 4 (3): Hal $87-92$

Yapanto, L. M., \& Olilingo, F. Z. (2020). The contribution of the fisheries and marine sectors to improving regional income. 22(10), 1307-1321.

Baruadi, A. S. R., Yapanto, L. M., \& Akuba, A. R. (2020). The welfare of tuna fishermen in Gorontalo District ; ( Case study in the village of Kayubulan, Gorontalo ). 29(4), 5289-5297.

Yapanto, L. M., Tanipu, F., Paramata, A. R., \& Actors, E. (2020). THE EFFECTIVENESS OF FISHERY COOPERATIVE INSTITUTIONS. 17(25), 1329-1338.

Yapanto, L. M., \& Olilingo, F. Z. (2020). The contribution of the fisheries and marine sectors to improving regional income. 22(10), 1307-1321.

[8] Muhaimin, A. W., Toiba, H., Retnoningsih, D., \& Yapanto, L. M. (2020). The Impact of Technology Adoption on Income and Food Security Of Smallholder Cassava Farmers: Empirical Evidence From Indonesia. 29(9), 699-706

[9] Setiawan, R., Pio, L., Cavaliere, L., Sankaran, D., Rani, K., Yapanto, L. M., Laskar, N. H., Raisal, I., Christabel, G. J. A., Setiawan, R., Petra, U. K., Airlangga, U., Pio, L., Cavaliere, L., $\&$ Foggia, U. (n.d.). Access to Financial Services and Women Empowerment, through Microfinance eligibility. 1, 841-859. 